\title{
BI for Sociologists
}

Note: One of the nine target associations of ACRL's Bibliographic Instruction Liaison Project is the American Sociological Association (ASA)(See CURL News, April 1982, pp. 131-32). The following article by Carla B. Howery describes part of the work of the Association and points out areas in which librarians and sociologists can cooperate. ACRL member Richard Werking, Trinity University, and a sociologist colleague will present a program on bibliographic instruction at the ASA annual meeting in San Francisco this month. Other ACRL members have prepared BI workshops to be given at six regional sociology meetings. Due to several problems only one of the workshops was actually given, but we plan to continue to work with ASA on this type of program.

Starting September 1 and continuing through August, 1983, Carolyn Kirkendall is serving as coordinator for the Bibliographic Instruction Liaison Project. Kirkendall, director of Project LOEX, the nation's largest BI clearinghouse, will coordinate program proposals with the various target associations and serve as a clearinghouse for information on discipline-related activities and bibliographic instruction. All project files have been transferred from ACRL Headquarters to Kirkendall. ACRL members who have not contacted us previously and who are interested in participating in this project should contact Carolyn Kirkendall at Project LOEX, Eastern Michigan University, Ypsilanti, MI 48197; (313) 487 0168.-Sandy Whiteley.

Professional organizations for sociologists exist on the national, regional, and state level. The American Sociological Association, based in Washington, is the national organization for sociologists. One part of ASA's mission is the Teaching Services Program.

This program is a multi-faceted effort to improve and support effective teaching within the discipline. Stemming from the ASA Projects on Teaching funding by grant monies from the Fund for the Improvement of Post-Secondary Education and the Lilly Foundation, the program is now a regular part of ASA operations.

1) The Teaching Resources Center (TRC) is a source for written materials about teaching sociology. Over fifty titles are offered for sale through TRC. Most of these products have been written by sociologists. The Center offers syllabi sets for ten courses, guidelines for training graduate students for teaching roles, curriculum development, specific teaching skills such as lecturing, and information on the institutional variables that iear upon effective teaching. The TRC is always looking for new products. One of its ser- vices is to provide display literature for state and regional society meetings. These literature tables allow colleagues to give the materials a first-hand review before ordering them and elicit feedback that is so helpful to TRC future development.

2) The Teaching Resources Group (TRG) is a network of over forty trained consultants who are available for departmental visits or teaching workshops. These sociologists have expertise in specific areas of teaching and are matched to the agenda of a department or workshop. TRG visitors can be an asset to a state society meeting that has part or all of its program focused on teaching. The expenses of the visitors need to be covered and a reasonable honorarium is requested for a departmental visit. Arrangements for TRG visits are made through Hans $O$. Mauksch, TD3W Medical Center, University of Missouri, Columbia, MO 65212.

The cooperative project between ACRL and ASA has as its goal the training of TRG members in library user skills so that they will be able to train other colleagues as part of TRG visits or workshop presentations.

3) Teaching Workshops are sponsored by the TSP on an annual basis. During 1980 and 1981 a national series of workshops was held each spring, calling attention to the teaching of sociology around the country. Librarians have been asked to come to these workshops as presentors and with the ACRL referrals, such presentations will be more common in future workshops.

Sage Publications publishes a journal called Teaching Sociology. It would be a useful addition to the journal to have articles on library user skills and bibliographic information for sociologists.

With all the teaching-related activity within TSP, there are other groups dovetailing and offering additional services for sociology teachers. The Section on Undergraduate Education is organized to work on teaching concerns for undergraduates. ASA members may join the Section for $\$ 7$ annual dues. Contact Fred Campbell, Sociology Department, University of Washington, Seattle, WA 98195, the chair for 1982.

Sociology courses lend themselves to a wide variety of library uses from searching through journal indexes to the use of secondary data sources in historical or demographic records. Faculty and students will benefit from continued ACRL/ASA cooperation. If you have ideas for projects, please contact Carla B. Howery, Director, Teaching Services Program, American Sociological Association, $1722 \mathrm{~N}$ Street, N.W., Washington, DC 20036; (202) 833-3410._Carla B. Howery. 


\section{GUIDELINE HELP WANTED}

The ACRL Standards and Accreditation Committee is compiling a list of all guidelines, checklists, standards, and standards-type documents that may apply to academic or research libraries. The list that appears below is derived from the ALA Policy Manual.

The Committee requests that anyone knowing of any standards that have been developed by an ALA or ACRL group and are not listed below, please contact Harvey Varnet, Library Director, Kentucky Wesleyan College, Owensboro, KY 42301; (502) 926-3111.

Access Policy Guidelines (1975); College Library Standards: Questions and Answers (1974); Evaluative Checklist for Reviewing a College Library Program Based on the 1975 Standards for College Libraries (1979); Guide to Methods of Library Evaluation (1968); Guidelines and Procedures for the Screening and Appointment of Academic Librarians (1977); Guidelines for Audio-Visual Services in Academic Libraries (1968); Guidelines for Bibliographic Instruction in Academic Libraries (1977); Guidelines for Branch
Libraries in Colleges and Universities (1975); Guidelines for Extended Campus Library Services (1982); Guidelines for the Security of Rare Book, Manuscript, and Other Special Collections (1982); Guidelines for Two-Year College Learning Resources Programs (1982); Guidelines on Manuscripts and Archives (1977); Joint Statement on Access to Original Research Materials (1979); Joint Statement on Faculty Status of College and University Librarians (1974); The Mission of an Undergraduate Library (Model Statement) (1979); Model Policy Concerning College and University Photocopying for Classroom, Research and $\mathrm{Li}$ brary Reserve Use (1982); Model Statement of Criteria and Procedures for Appointment, Promotion in Academic Rank, and Tenure for College and University Librarians (1973); Relator Terms for Rare Books, Manuscripts, and Special Collections Cataloging (1981); Standards for College Libraries (1975); Standards for Faculty Status for College and University Librarians (1974); Standards for University Libraries (1979); Statement on Collective Bargaining (1975); Statement on the Terminal Professional Degree for Academic Librarians (1975); and Use and Effectiveness of the 1975 Standards for College Libraries (1981).

\section{Chapter News}

Thirty-two regional and state ACRL chapters now cover thirty-six states and one Canadian province, and provide opportunities for local participation for nearly 7,000 ACRL members who live within those areas. A Louisiana Chapter was approved by the ACRL Board of Directors at the annual conference.

\section{CHAPTER ACTIVITIES}

- The Delaware Valley Chapter held its Spring Meeting at the Mendenhall Inn, Kennett Square, on May 14. Patricia Joan Austin spoke on the topic, "Getting along with Patrons and Fellow Employees."

- The Eastern New York Chapter discussed "How Far Should the Librarian Go in Helping the User" at its Spring Conference on April 2. The afternoon session covered "How Much Should the Librarian Tell the User?" regarding both medical and legal information.

- The Greater New York Metropolitan AREa CHAPTER is sponsoring an International Enrichment Conference for Librarians designed to acquaint librarians with selected library and education facilities and publishing houses in the People's Republic of China. The 23-day tour includes visits to Peking, Shanghai, Canton, Nan- king, and other cities, and will be executed in connection with the China International Travel Service. Conference attendees will depart Los Angeles on July 1 after ALA Annual Conference.

- The Illinois Chapter conducted its Spring Conference, "The Person in the Academic Librarian," on April 30 at Lake Forest College. Topics included: Work Schedules: Meshing 9 to 5 with a Personal Life; Faculty Status for Librarians; Librarian Burnout; and Career Alternative Planning for Librarians.

- The Iowa Chapter presented a workshop on "Coping" on April 6 which included sessions on: Collection Development in an Era of NonGrowth; Alternatives to Building; Preservation: A Solution to Hard Times; and Job Stress.

- The Kansas Chapter will hold their Fall Meeting in Manhattan at the Kansas Holidome on October 13-15. Herbert White will be featured as a preconference speaker.

- The Michigan Chapter will offer a Serials Management Institute as part of the Fall Conference program of the Michigan Library Association, October 27-29 in Grand Rapids. The morning sessions will cover various aspects of serials and the user, while the afternoon meetings will be devoted to technical services concerns.

The chapter reports continued success with its 